\title{
Influence of nitrogen fertilizer sources and lime applications on water use efficiency of oats (Avena sativa L.) under no-tillage management in andisols of Southern Chile
}

\begin{abstract}
Food production under rainfedagriculture, is limited due to soil water storage, mainly from low and variable rainfall. The aim of this study was to evaluate the effects of nitrogen fertilization sources and lime applications on WUE of oats (Avena sativa L.), under notillage management in a Typic Haploxerand soil, during the growing season 2008-09. The experimental design was a randomized complete block with three replicates and four treatment.The treatments were: $\left(\mathrm{T}_{1}\right)$ : triple superphosphate+sodium nitrate; $\left(\mathrm{T}_{2}\right)$, urea+mono-ammonium phosphate, MAP; $\left(\mathrm{T}_{3}\right)$ : urea +MAP + $750 \mathrm{kgha}^{-1}$ lime and $\left(\mathrm{T}_{4}\right)$ urea + MAP $+1500 \mathrm{kgha}^{-1}$ lime. Evapotranspiration was measured by the water balance method olumetric soil water content was monitored with a neutron probe. Dry matter was measured in the phenological stages of tillering $(\mathrm{T})$, panicle emergence $(\mathrm{PE})$, milky grain (MG) and dough grain (DG).Total dry matter and grain yield were measured at maturity. Water use efficiency was determined in the phenological stages of: tillering $(\mathrm{T})$-panicle emergence (PE), PE-milky grain (MG) and MG-dough grain (DG). The results showed that treatments with ammonium fertilizers and lime application enhanced WUE. The higher WUE was observed between PE-MG. The ammonium fertilization $\left(\mathrm{T}_{2}\right)$ showed lower values for WUE, rate growth and harvest index. The source of nitrogen did not affect crop evapotranspiration and the NP fertilization with lime improves the WUE of oats with notillage management in Andisols of Southern Chile.
\end{abstract}

Keywords: water use efficiency, nitrogen fertilizer, lime, water balance, oats
Volume 4 Issue 4 - 2020

\author{
C Quezada,' M Sandoval,' E Zagal,' D. \\ Lizama,' MA Soriano \\ 'Faculty of Agronomy, University of Concepción, Chile \\ ${ }^{2}$ Department of Agronomy, University of Córdoba, Campus \\ Universitario de Rabanales, Spain
}

\author{
Correspondence: Celerino Quezada, Faculty of Agronomy, \\ University of Concepción, Chile, Tel 56-42-2208927,
} Email cequead@udec.cl

Received: June 25, 2020 | Published: July 10, 2020

\section{Introduction}

Irrigated agriculture is the primary user of diversed water globally, reaching a proportion that exceeds $70-80 \%$ of the total in the arid and semi-arid zones. ${ }^{1}$ Scarcity of water resources and growing competition for water in many sectors reduce its availability for irrigation. ${ }^{2}$ Most agricultural production in the world is not irrigated and depends of rainfall and therefore, capture of rainfall for crop use is critical in determining crop productivity. ${ }^{3}$

In facts, rainfed agriculture is practiced on $80 \%$ of the world's agricultural land area, and generates about $70 \%$ of the world's staple foods, including most of the food in poor communities. ${ }^{4}$ In developing countries the large gaps between actual and attainable in rainfed yields, in many regions of the world suggest a large untapped potential for yield increases. ${ }^{5}$

Water scarcity and increasing demands for agricultural products create much debate about improvement of water use efficiency in the agricultural sector. ${ }^{6}$ There are two broad strategies for increasing yields in rainfed agriculture: (1) capturing more water and allowing it to in filtrate into the root zone; and (2) using the available water more efficiently by increasing the plant water uptake capacity and/or reducing non-productive soil evaporation. ${ }^{5}$ In addition, a possible way to increase dry land crop yield is to manage the transpiration so that more water is used during the vegetative phase when vapor pressure deficit is lower.
Water use efficiency (WUE) represents a given level of biomass or grain yield per unit of water used by the crop. ${ }^{8-10}$ In rainfed agriculture, the WUE is linked to the effectiveness of the use of precipitation because there is not other source of water available. ${ }^{8}$ However, up to $50 \%$ of the rainfall in semi-arid areas is lost from the fields as non-productive soil evaporation. Options to reduce soil evaporation include dry planting, conservation agriculture and mulching. ${ }^{5}$ According to Howell ${ }^{11}$ the main pathways for enhancing WUE in irrigated agriculture are to increase the output per unit of water, reduce losses of water to unusable sinks, reduce water degradation and relocate water to higher priority uses.

In order to increase water storage within the soil profile is necessary to increase plant available soil water. ${ }^{2}$ Soil management practices affect the processes of evapotranspiration by modifying the available energy, the available water in the soil profile, or the exchange rate between the soil and the atmosphere. ${ }^{8}$ Many studies have shown the effectiveness of a no-tillage system in the soil water storage. ${ }^{12-14}$ It has been stated that no-tillage enhances the hydraulic properties of the soil, ${ }^{15}$ since the maintenance of crop residues on the soil surface result in an increased rainfall infiltration and a reduction in evaporation. ${ }^{16}$

Water is limiting factor for grain production in rainfed farming systems of many semiarid dryland regions, where cereal crops are frequently grown under a crop- fallow system, one crop every 2 years. ${ }^{17}$ Greater yield per unit rainfall is one of the most important challenges in dry land agriculture. ${ }^{9}$ Therefore, to increase the yield is essentialto optimize water and nitrogen use..$^{8,18-21}$ 
The Chilean soils derived from volcanic ashes showed acidic $\mathrm{pH}$, high extractable $\mathrm{Al}$ and high $\mathrm{P}$ fixation..$^{22}$ Andisols located in the Andean foothills of Southern Chile are used under rainfed conditions with the traditional rotation oats - wheat. Nevertheless, increasing crop yield requires improved rainfall storage efficiency and proper rates the soil acidification by using residue management, tillage systems and nitrogen fertilization. No-tillage management favors water accumulation in the soil profile and greater root growth. ${ }^{19,23,24}$ In addition, it has been shown that mulching with crop residue can improve water use efficiency by $10-20 \%$ through reduced soil evaporation and increased plant transpiration. ${ }^{18,25}$

The agronomic advantages of conservation tillage have also been questioned in terms of soil water storage efficiency during and at the end of the fallow period. ${ }^{17}$ On the contrary, the use of crop residues to conserve soil and water in arid and semiarid areas is becoming increasingly important. ${ }^{23}$ Therefore, the aim of this study was to evaluate the effectiveness of different sources of nitrogen fertilization and lime on water use efficiency in oat crops under with no-tillage management in Andisols of Southern Chile.

\section{Materials \& methods}

\section{Site description}

A field experiment was carried out in El Carmen with geographic coordinates $36^{\circ} 56^{\prime} \mathrm{S}, 71^{\circ} 59^{\prime}$ Wat an altitude of about $290 \mathrm{~m}$ above the sea level. This area has a Mediterranean climate and it is located in the central southzone of Chile. The average annual rainfall is $1200 \mathrm{~mm}$ with a $77 \%$ falling in May, June, July and August. Annual evapo transpiration is reported as $1100 \mathrm{~mm}$, with a dry period of 3-4 months and with 5-6 frost-free months. Average annual mean temperature for this area is $13.6^{\circ} \mathrm{C}$ with an average temperature of $3.8 \mathrm{C}^{\circ}$ in the coldest month (June) and $19.7^{\circ} \mathrm{C}$ in the hottest month (January). Annual mean relative humidity is $71 \%{ }^{26}$

The soil corresponds to a medial, amorphic, thermic Typic Haploxerands, derived from volcanic ashes. It is a deep and porous soil with good drainage. Soil texture is silt loam, with a clay proportion of $27.8 \%$, silt $38.4 \%$ and sand $33.8 \%$. Soil bulk density was $0,94 \mathrm{Mgm}^{-3}$ and soil water content at field capacity and wilting point were $63.72 \%$ and $33,55 \%$ by weight, respectively.

\section{Experimental design}

The field experiment was conducted in the 2008-09 growing season with oats (Avena Sativa L. ) in a long-term crop rotation wheat (Triticumaestivum L.) and oats (Avena sativa L.) sowed during 19961997 growing season under no-tillage management The sowing was carried out with $140 \mathrm{kgha}^{-1}$ seed dose . The nitrogen fertilization was divided in $1 / 3$ sowing and 2/3 tillering. In addition, $150 \mathrm{~kg} \mathrm{P}_{2} \mathrm{O}_{5} \mathrm{ha}^{-1}$ and $120 \mathrm{~kg} \mathrm{~K}_{2} \mathrm{O} \mathrm{ha}^{-1}$ were applied. The experiment was laid out in a randomized complete block design with three replicates $(10 \times 12 \mathrm{~m})$ and four treatments. The treatments were: T1:triple superphosphate $325 \mathrm{kgha}^{-1}+$ sodium nitrate , $750 \mathrm{~kg} \mathrm{ha}{ }^{-1} ; \mathrm{T} 2$ :mono-ammonium phosphate MAP, $300 \mathrm{kgha}^{-1}+$ urea, $260 \mathrm{~kg} \mathrm{ha}^{-1}: \mathrm{T}_{3}$ : lime, $750 \mathrm{kgha}^{-1}$ +MAP,300 kg ha ${ }^{-1}$ + urea, $260 \mathrm{kgha}^{-1}$; T4: lime1500 $\mathrm{kgha}^{-1}+$ MAP, 300 $\mathrm{kgha}^{-1}+$ urea, $326 \mathrm{~kg} \mathrm{ha}^{-1}$. Each experimental plot was $120 \mathrm{~m}^{2}$ with 2 $\mathrm{m}$ between plots.

\section{Water balance}

Evapotranspiration (ET) was calculated using the following equation:

$$
\mathrm{ET}=\Delta \mathrm{W}+\mathrm{P}-\mathrm{D}
$$

Where $\Delta \mathrm{W}(\mathrm{mm})$ is the change in soil water storage between two soil moisture content measurements, $\mathrm{P}(\mathrm{mm})$ is growing seasonal rainfall and $\mathrm{D}(\mathrm{mm})$ is downward drainage out of the root zone .Soil water content was monitored using a neutron probe (CPN, 503-DRHydroprobe, Campbell Pacific Nuclear International, California., USA)) at 20, 40,60 cm depth .This device was calibrated against volumetric soil water content $(\Theta v)$ and neutron count rate $(\mathrm{CR})$, using a calibration curve $(\Theta \mathrm{v}=41,721 \mathrm{CR}-53,015)$. Soil water content was measured in the phenological stages of tillering (23 August), panicle emergency (11 October), milky grain (15 November) and dough grain (16 December). Rainfall was obtained from the automatic meteorological station located in the experimental area. Drainage rate was determined by measurements of volumetric water content between 40 and $60 \mathrm{~cm}$-depth using the following relationship:

$$
\left.\mathrm{D}=(\Delta \Theta / \Delta \mathrm{t}) \mathrm{z}=\left(\Theta_{\mathrm{v} 2}-\Theta_{\mathrm{v} 1}\right) / \mathrm{t}_{1}-\mathrm{t}_{2}\right) \mathrm{z}
$$

Where: $\mathrm{D}(\mathrm{mm})$ is the drainage out root zone; $\Delta \Theta\left(\mathrm{cm}^{3} \mathrm{~cm}^{-3}\right)$ is the variation of soil volumetric water content as function of time; $\Delta \mathrm{t}($ days $)$ is the timing and $\mathrm{z}(\mathrm{cm})$ is soil depth.

\section{Water use efficiency}

Water use efficiency (WUE) was calculated for both dry matter and grain yield by dividing crop yield by evapotranspiration. Samples of fresh matter were obtained using the square method $(0.25 \times 0.25$ $\mathrm{m}$ ). Then, samples were oven dried at $65^{\circ} \mathrm{C}$ for $72 \mathrm{~h}$ (Memmert, UFP 800 RR, Schwabach, Germany) and the dry weight was determined .Dry matter yield was measured, in the phenological stages of tillering $(\mathrm{T})$, panicle emergency $(\mathrm{PE})$, milky grain $(\mathrm{MG})$ and dough grain $(\mathrm{DG})$.

At harvest, the grain yield was measured in the five central files of $3 \mathrm{~m}$ length for each plot, and the mean grain yield was expressed as $\mathrm{kg} \mathrm{ha}^{-1}$. The harvest index (HI) was calculated by expressing the grain yield over the final total dry matter yield. WUE was determined by dividing grain yield by evapotranspiration.

\section{Statistical analysis}

Data collected were subjected to analysis of variance (ANOVA). Differences between means of treatments were declared significantly different using Tukey test $(\mathrm{p}<0.05) .{ }^{27}$

\section{Results and discussion}

\section{Volumetric soil water content and soil water storage}

Figure 1 shows the changes of volumetric soil water contentat $0-20$ $\mathrm{cm}$ and $20-40 \mathrm{~cm}$ soil layer. Soil water content showed a similar pattern for the two depths, but it changed in the different phenological stages due to the differences in seasonal rainfall and crop water requirements, reaching its highest value at milky grain where soil moisture was close to FC, due to $17 \mathrm{~mm}$ rainfall before measurement (Figure 2). Between the stages of T-PE, the $\Theta v$ was under the threshold level (TL) as a result of the increase in crop water requirements. The $\Theta v$ showed a decrease in the panicle emergency stage due to a low rainfall of $18 \mathrm{~mm}$. However, the highest $\Theta v$ was obtained at milky grain, with statistical differences $(\mathrm{p} \leq 0,05)$ as compared with panicle emergency and dough grain. This can be explained for the higher rainfall $(37 \mathrm{~mm})$ in October and the crop residues on the soil surface that decreased soil evaporation. On the other hand, Ovat dough grain (16 December) was lower that PWP as a result of higher evapotranspiration and rainfall scarcity in December. 

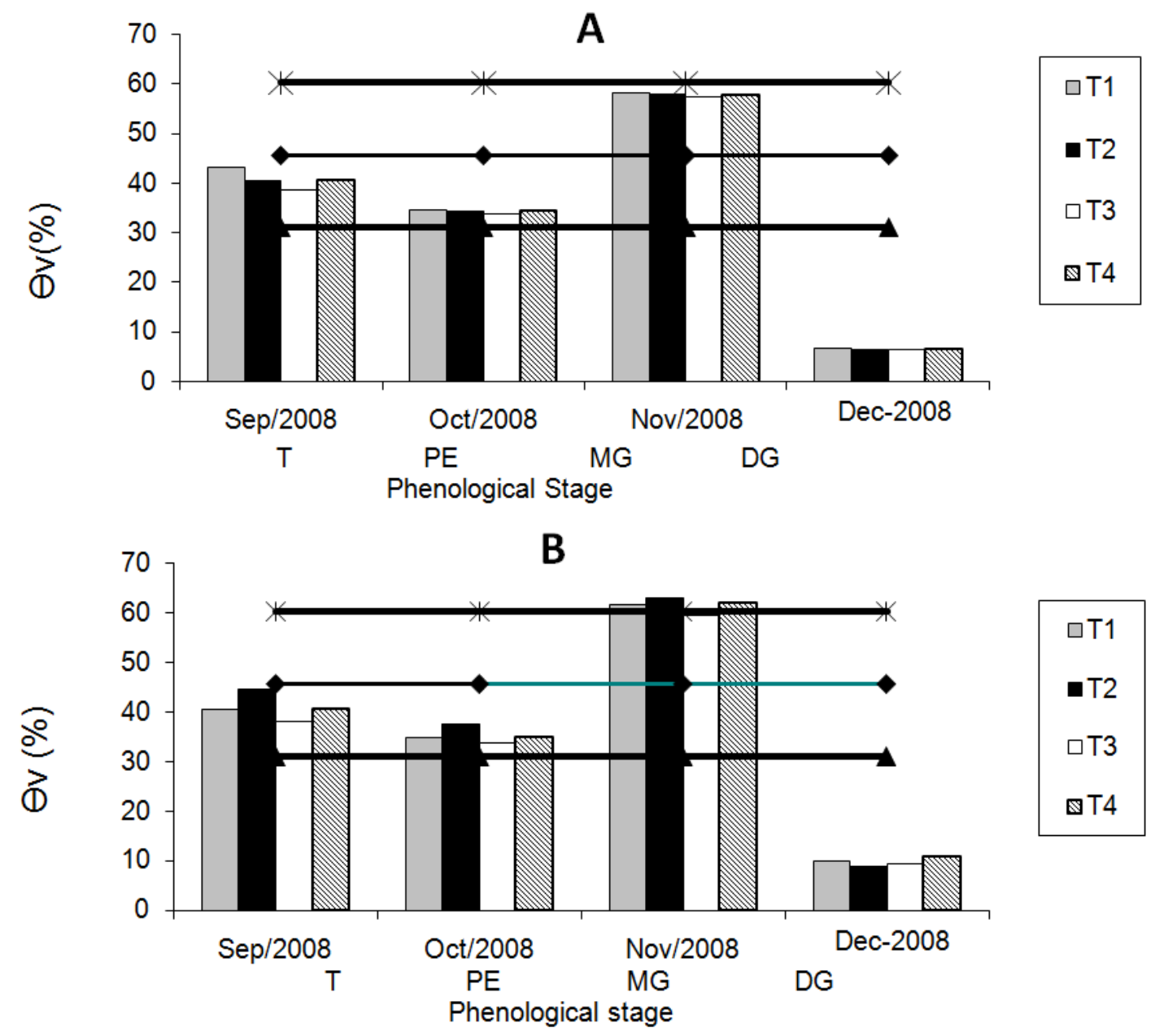

Figure I Volumetric soil water content, $\Theta v(\%)$ in the different phenological stages of an oat crop under no-tillage management with different nitrogen fertilization sources and lime applications in aTypic Haploxer and soil at $20 \mathrm{~cm}(\mathrm{~A})$ and $40 \mathrm{~cm}(\mathrm{~B})$ depth.

FC, Field capacity; PWP, permanent wilting point; TL, threshold level (50\%HA); HA, water availability (FC-PWP); Өv, volumetric soil water content; T, tillering; PE, panicle emergency; MG, milky grain; DG, dough grain.

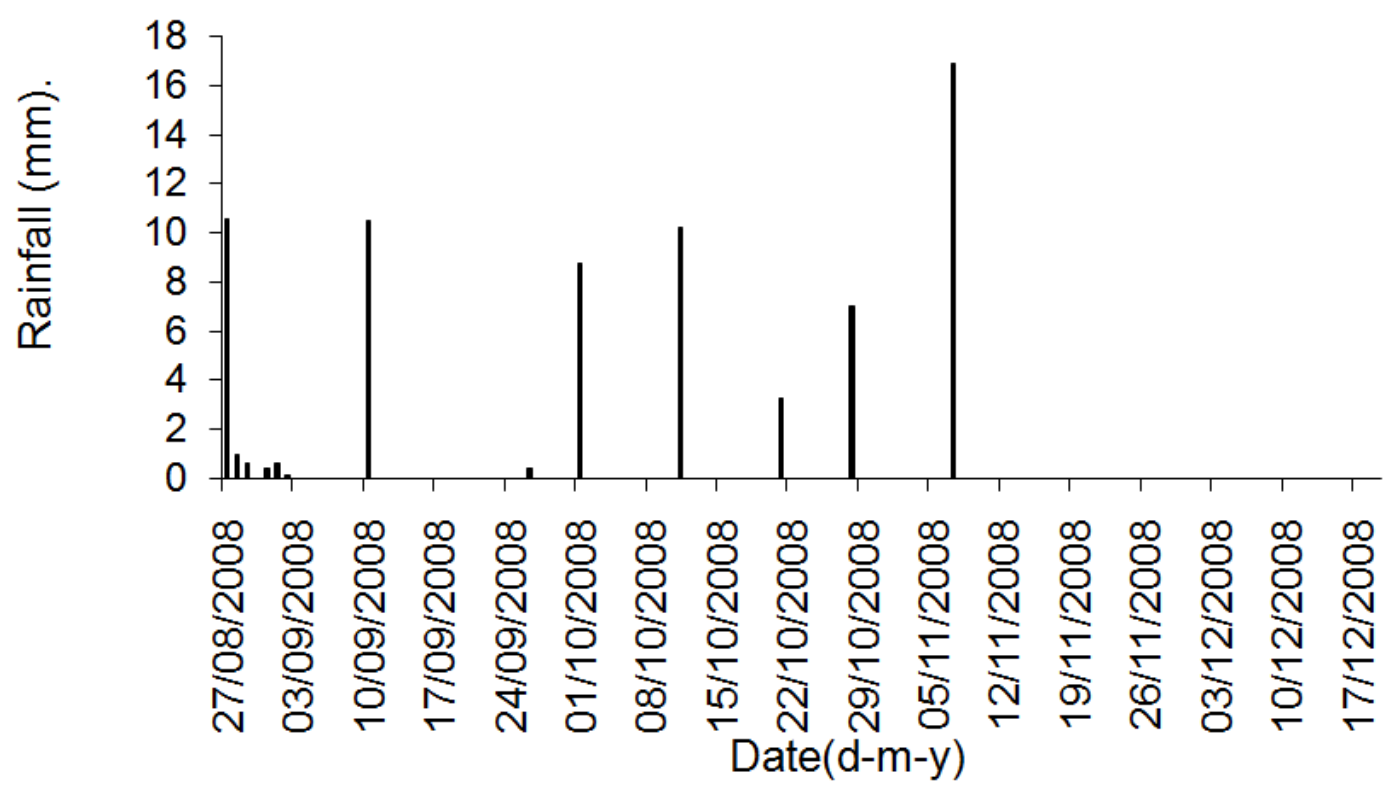

Figure 2 Rainfall during the experimental period in the site experimental, El Carmen, Chillán, Chile. 
There was no significant difference $(P \leq 0,05)$ between sources of fertilization and soil water storage at $0-20$ y $20-40 \mathrm{~cm}$-depth in the different phenological stages of the crop (Table 1). This is explained by the fact that energy state of soil water depends on capillarity, pore size distribution and particle size distribution. On the contrary, sources of fertilization have positive effects on the root development and water uptake. ${ }^{21}$ However, T3 showed the lowest levels for soil water storage at 20-40 cm-depthat the T-PE-MG phenological stages, which can be explained for the higher water uptake due to greater root growth. According to Pala et al..$^{20} \mathrm{~N}$ application can increase the ability of crop to utilize soil available water.

Table I Soil water storage $(\mathrm{mm})$ in the different phenological stages of an oat crop under no-tillage management with different nitrogen fertilization sources and lime applications in a Typic Haploxer and soil at 0-20 and $20-40 \mathrm{~cm}$ depth

\begin{tabular}{llllll}
\hline \multirow{5}{*}{ Depth $(\mathbf{c m})$} & Phenological stage \\
\cline { 2 - 6 } $0-20$ & Treatments & Tillering & Panicle emergency & Milky grain & Dough grain \\
\cline { 2 - 6 } & TI & $87 \mathrm{aBC}$ & $69 \mathrm{aB}$ & $116 \mathrm{aC}$ & $132 \mathrm{aA}$ \\
& T2 & $81 \mathrm{aB}$ & $68 \mathrm{aB}$ & $116 \mathrm{aC}$ & $127 \mathrm{aA}$ \\
& T3 & $77 \mathrm{aB}$ & $68 \mathrm{aB}$ & $115 \mathrm{aC}$ & $130 \mathrm{aA}$ \\
& T4 & $8 \mathrm{IaBC}$ & $69 \mathrm{aB}$ & $116 \mathrm{aC}$ & $133 \mathrm{aA}$ \\
& TI & $81 \mathrm{aB}$ & $70 \mathrm{aAB}$ & $123 \mathrm{aB}$ & $202 \mathrm{aA}$ \\
& T2 & $89 \mathrm{aB}$ & $75 \mathrm{aB}$ & $126 \mathrm{aC}$ & $176 \mathrm{aA}$ \\
& T3 & $76 \mathrm{~B}$ & $68 \mathrm{aB}$ & $119 \mathrm{aC}$ & $189 \mathrm{aA}$ \\
& T4 & $82 \mathrm{aB}$ & $70 \mathrm{a}$ & $125 \mathrm{aC}$ & $219 \mathrm{aA}$
\end{tabular}

Columns with diferent lowercase letters and files with different capital letters differ significantly, Tukey's test $(P<0.05)$

\section{Evapotranspiration}

The ET estimated by water balance is shown in Table 2. These results showed that root water-uptake is similar at 0-20 and 20-40 $\mathrm{cm}$-depth, obtaining the highest water consumption between PE-MG, representing a $40 \%$ of total crop water extraction of soil profile.
No significant differences $(\mathrm{p} \leq 0,05)$ were observed between treatments, except during T- PEin $\mathrm{T}_{1}$ (triple superphosphate+sodium nitrate) and $\mathrm{T} 2$ (MAF+ urea). This can be explained when considering that $\mathrm{NH}_{4}^{+}$applications decrease the ability of crop to utilize soil water available. ${ }^{20}$ Regarding phenological stages, significant differences $(\mathrm{p} \leq 0,05)$ were observed in $\mathrm{T} 3$ at $0-20 \mathrm{~cm}$-depth and in $\mathrm{T}_{3}$ and $\mathrm{T}_{4}$ at 20-40 cm-depth.

Table 2 Evapotranspiration $(\mathrm{mm})$ in the different phenological stages ofan oat crop under no-till age management with different nitrogen fertilizer sources and lime applications in a Typic Haploxer and at 0-20, 20-40 and 0-40 cm-depth

\begin{tabular}{|c|c|c|c|c|c|}
\hline \multicolumn{6}{|c|}{ Phenological stage } \\
\hline Depth (cm) & Treatments & T-PE & PE-MG & MG-DG & Total \\
\hline \multirow[t]{4}{*}{$0-20$} & TI & $4 \mid \mathrm{bA}$ & $57 \mathrm{aA}$ & $5 \mathrm{I} A \mathrm{~A}$ & $149 a$ \\
\hline & $\mathrm{T} 2$ & $29 \mathrm{aA}$ & $5 \mathrm{I}$ aA & $45 \mathrm{aA}$ & $125 \mathrm{a}$ \\
\hline & T3 & $34 \mathrm{abA}$ & $59 \mathrm{aB}$ & $51 \mathrm{aB}$ & $144 \mathrm{a}$ \\
\hline & $\mathrm{T} 4$ & $36 \mathrm{abA}$ & $53 \mathrm{aA}$ & $51 \mathrm{aA}$ & $140 \mathrm{a}$ \\
\hline \multirow[t]{4}{*}{$20-40$} & TI & $32 \mathrm{aA}$ & $60 \mathrm{aA}$ & $53 \mathrm{aA}$ & $145 \mathrm{a}$ \\
\hline & $\mathrm{T} 2$ & $26 \mathrm{aA}$ & $54 \mathrm{aA}$ & $53 \mathrm{aA}$ & $133 a$ \\
\hline & T3 & $3 \mathrm{laA}$ & $59 \mathrm{aB}$ & $51 \mathrm{aB}$ & $14 \mid \mathrm{a}$ \\
\hline & $\mathrm{T} 4$ & $3 \mathrm{IaA}$ & $61 \mathrm{aB}$ & $55 \mathrm{aAB}$ & $147 \mathrm{a}$ \\
\hline \multirow[t]{2}{*}{$0-40$} & $\mathrm{TI}$ & 73 & 117 & 104 & 294 \\
\hline & $\mathrm{T} 2$ & 55 & 105 & 98 & 258 \\
\hline T3 & 65 & 118 & 102 & 285 & \\
\hline $\mathrm{T} 4$ & 67 & 114 & 106 & 287 & \\
\hline
\end{tabular}

Columns with diferent lowercase letters and files with different capital letters differ significantly, Tukey's test $(P<0.05)$. T, tillering; PE, panicle emergency; MG, milky grain; DG, dough grain 
The highest ET and dry matter production was obtained between $\mathrm{PE}-\mathrm{MG}$, for all treatments, due to the increase in temperature during grain filling when the crop shows the highest hydric requirements. This is in agreement with Angus and van Herwaarden (2001) who reported that additional biomass from $1 \mathrm{~mm}$ of ET before anthesis was $30 \mathrm{~kg} \mathrm{ha}^{-1}$ and $35 \mathrm{~kg} \mathrm{ha}^{-1}$ after anthesis, with high $\mathrm{N}$ applied.

The lowest ET values in the different phonological stages were found with the application of MAP and urea (T2) due to low plant density and the effects of soil acidification $(\mathrm{pH}=4,05)$. On the contrary, treatments $\mathrm{T} 3(\mathrm{pH}=5,70)$ and $\mathrm{T} 4(\mathrm{pH}=6,52)$ presented the higher ET, due to higher root development and water uptake as a result of lime application.

Evapotranspiration was very similar between treatments $\mathrm{T}_{1}, \mathrm{~T}_{3} \mathrm{y}$ $\mathrm{T}_{4}$ with 294, 285 and $287 \mathrm{~mm}$, respectively. On the other hand, in $\mathrm{T}_{2}$ was $258 \mathrm{~mm}$, decreasing in $12.5 \%$ due to $\mathrm{NH}_{4}^{+}$fertilization.

\section{Drainage}

Figure 3 shows that the highest drainage rate was recorded in $\mathrm{T}_{2}$ with $55 \mathrm{~mm}\left(0.65 \mathrm{mmday}^{-1}\right)$ due to lower root growth and leaf area. However, it can also be observed that drainage rate values were similarin the other treatments (Figure 3), reaching the highest value between PE-MG phenological stages, for the effects of seasonal rainfall and soil acidity. In general, the drainage from the root zone was low with values of $30 \mathrm{~mm}$ in $\mathrm{T}_{1}, 22 \mathrm{~mm}$ in $\mathrm{T}_{3}$, and $29 \mathrm{~mm}$ in $\mathrm{T}_{4}$ during the growing season. These values result in low drainage rate of 0,36 in $\mathrm{T}_{1} ; 0,25$ in $\mathrm{T} 3$ and $0,35 \mathrm{~mm}^{\text {day }}{ }^{-1}$ in $\mathrm{T}_{4}$, which may be explained for a higher soil water retention and lower soil hydraulic conductivity of Andisols that ranged from 2 to $8 \times 10^{-9} \mathrm{mseg}^{-1} \cdot{ }^{28}$ On the other hand, Lampurlanés and Cantero-Martíne $z^{23}$ determined that the adoption of no-tillage decreased the hydraulic conductivity due to reduction in soil porosity in semiarid conditions. Furthemore, Angus and van Herwaarden ${ }^{7}$ estimated that the term of drainage is usually negligible on flat land in semiarid and subhumid conditions, while it is taken as zero in other studies. ${ }^{20,21,24}$ On the other hand, Tan et al. ${ }^{29}$ reported that tillage had very little effect on tile drainage.

\section{Yield parameters}

Biomass was affected by the nitrogen source. The lowest yields were found with theT2 (MAP+urea), due to soil acid pH of 4.05 (Table 3 ). The highest dry matter yield and grain yield were obtained in $T_{3}$ and $T_{4}$ since lime application improved the soil structure and increased water storage. Therefore, management of nitrogen and phosphorus fertilization is crucial to obtain optimum $\mathrm{pH}$ for the crop in Andisols.

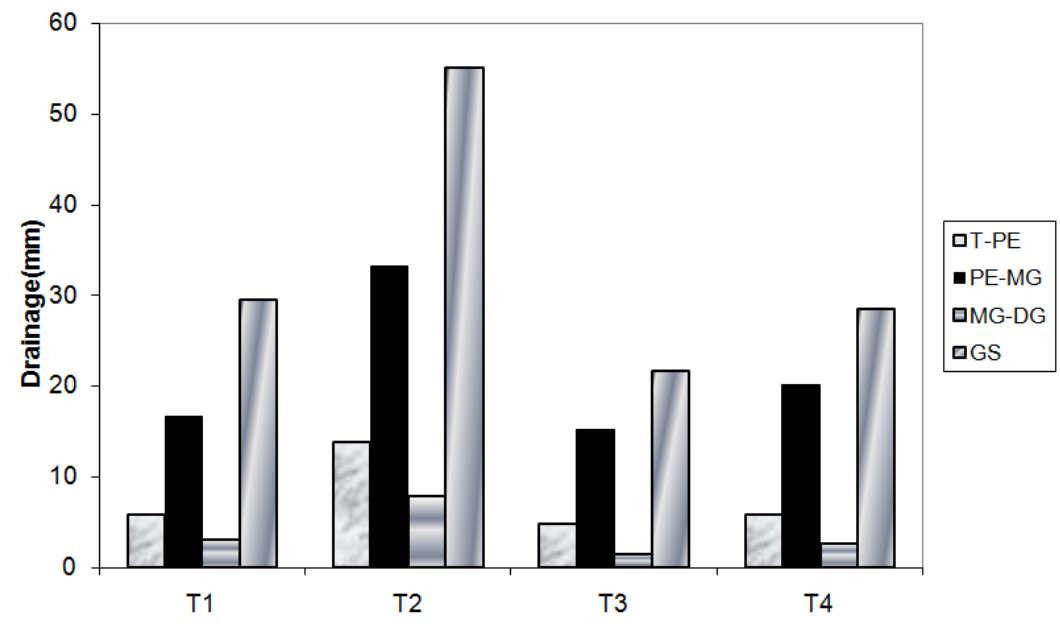

Figure 3 Drainage rate $(\mathrm{mm})$ in the different phenological stages of an oat crop under no-tillage management with different nitrogen fertilization sources and lime applications in a Typic Haploxer and soil.

T, tillering; PE, panicle emergency; MG, milky grain; DG, dough grain; GS, growing season.

Table 3 Soil acidity of an oat crop under no-tillage management with different nitrogen fertilizer sources and lime applications in a Typic Haploxer and soil

\begin{tabular}{ll}
\hline Treatments & $\mathbf{p H}$ \\
\hline TI & $6, \mathrm{II} \mathrm{b}$ \\
T2 & $4,05 \mathrm{~d}$ \\
T3 & $5,70 \mathrm{c}$ \\
T4 & $6,52 \mathrm{a}$
\end{tabular}

Column with different lowercase letters differ significantly, Tukey's test ( $\mathrm{P} \leq$ 0.05)

The highest production of dry matter and growth rate was found between PE-MG (Table $4 \& 5)$ showing statistical differences $(\mathrm{P} \leq 0,05)$ as compared with the others phenologicalstages in all treatments, with the exception of $\mathrm{T}_{4}$ that showed the highest growth rate. At the stages of MG -DG the growth rate showed the lowest value in $T_{2}$, probably because during the filling grain the crop did not have enough roots to extract soil water during the filling grain stage.$^{20}$ This suggests that the phenological stage corresponding to PE-MG is the period with the highest water requirements, period in which the crop needs greater soil water availability.

Respect to grain yield (Table 6) the results show that values were higher in the treatments with lime applications and showed statistical differences $(P \leq 0,05)$ as compared with $T_{2}$ (ammonium fertilization without lime), $\mathrm{T}_{4}$ was the treatment that presented the highest yield with a value of $4650 \mathrm{~kg}$ grain $\mathrm{ha}^{-1}$.

The highest values for growth rate were obtained between PE-MG, with $203 \mathrm{~g} \mathrm{DM}$ day $^{-1}$ in $\mathrm{T}_{3}$ (ammonium fertilization $+750 \mathrm{~kg} \mathrm{ha}^{-1}$ lime). 
Therefore, lime additions have positive effects to correct soil $\mathrm{pH}$ and increase the root growth in Chilean Andisols..$^{30}$ The growth rate in the vegetative phase and grain filling was lower, especially in treatment
$\mathrm{T}_{2}$ (Figure 4) demonstrating that the use of ammonium-based $\mathrm{N}$ fertilizers is not recommended because the acidify soils and enhance $\mathrm{P}$ adsorption capacity.

Table 4 Dry matter ( $\left.\mathrm{kg} \mathrm{DM} \mathrm{ha}^{-1}\right)$ in the different phenological stage of an oat crop under no-tillage management with different nitrogen fertilizer sources and lime applications in a Typic Haploxer and soil

\begin{tabular}{|c|c|c|c|c|}
\hline \multirow[b]{2}{*}{ Treatments } & \multicolumn{4}{|c|}{ Phenological Stages } \\
\hline & Tillering & Panicle emergency & Milky grain & Dough grain \\
\hline TI & $883 \mathrm{aA}$ & $2755 \mathrm{aA}$ & $7811 \mathrm{aB}$ & $9789 \mathrm{aC}$ \\
\hline $\mathrm{T} 2$ & $752 a A$ & $2828 \mathrm{aAB}$ & $7629 \mathrm{aBC}$ & $8235 \mathrm{aC}$ \\
\hline T3 & $115 \mathrm{IaA}$ & $3830 \mathrm{aAB}$ & $9717 \mathrm{aBC}$ & $12.000 \mathrm{aC}$ \\
\hline T4 & $1004 \mathrm{aA}$ & $3347 \mathrm{aAB}$ & $7768 \mathrm{aBC}$ & $11.156 \mathrm{aC}$ \\
\hline
\end{tabular}

Columns with diferent lowercase letters and files with different capital letters differ significantly, Tukey's test $(P<0.05)$

Table 5 Growth rate (g DM day ${ }^{-1}$ ) in the different phenological stages of an oat crop under no-tillage management with different nitrogen fertilizer sources and lime applications in a Typic Haploxer and soil

\begin{tabular}{llll}
\hline & \multicolumn{2}{l}{ Phenological stages } \\
\cline { 2 - 4 } Treatments & T-PE & PE-MG & MG-DG \\
\hline TI & $38 \mathrm{aA}$ & $174 \mathrm{aB}$ & $32 \mathrm{aA}$ \\
T2 & $42 \mathrm{aA}$ & $166 \mathrm{aB}$ & $10 \mathrm{bA}$ \\
T3 & $55 \mathrm{aA}$ & $203 \mathrm{aB}$ & $37 \mathrm{aA}$ \\
T4 & $48 \mathrm{aA}$ & $152 \mathrm{aB}$ & $55 \mathrm{aA}$
\end{tabular}

Columns with diferent lowercase letters and files with different capital letters differ significantly, Tukey's test $(P<0.05)$. T, tillering; PE, panicle emergency; MG, milky grain; DG, dough grain

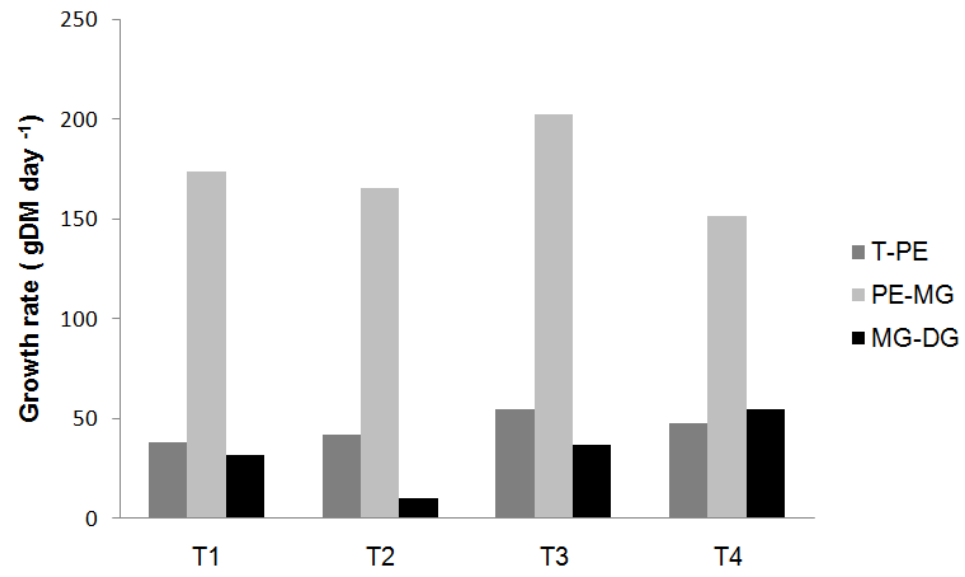

Figure 4 Growth rate (g DM day ${ }^{-1}$ ) in the different phenological stages of an oat crop under no-tillage management to different nitrogen fertilizer sources and lime applications in a Typic Haploxer and soil.

T, tillering; PE, panicle emergence; MG, milky grain; DG, dough grain.

Harvest index (Table 6, Figure 5) did not present statistical differences $(\mathrm{P} \leq 0,05)$ between treatments. However, $\mathrm{T}_{2}$ showed the lowest $\mathrm{HI}$, due to a decrease in grain yield as a result of $\mathrm{NH}_{4}^{+}$ fertilization .This can be explained because the processes of grain filling were more affected that the growth period, reaching the lowest growth rate between MG-DG (Table 7). This results are in agreement with Caviglia y Sadras. ${ }^{31}$ who determined HI ranged from 0,28 to 0,47 with 80 and $160 \mathrm{~kg} \mathrm{Nha}^{-1}$ in a crop wheat, respectively.

\section{Water use efficiency (WUE)}

Table 8 shows WUE of dry matter perphenological stage with different source of fertilization. Results showed no significant differences $(\mathrm{P} \leq 0,05)$ among treatments and sources of fertilization. Only $\mathrm{T}_{2}$ showed significant differences between T-PE and PE-MG, obtaining the lowest WUE during the period MG-DG, with a value of $6,77 \mathrm{~kg} \mathrm{MS} \mathrm{ha}^{-1} \mathrm{~mm}^{-1}$. The crop phase between PE-MG showed the highest WUE for all treatments, obtaining a value of 50,42 $\mathrm{kg} \mathrm{MS} \mathrm{ha}^{-1}$ $\mathrm{mm}^{-1}$ in $\mathrm{T}_{3}$. However, the phase between MG-DG showed the highest WUE in $\mathrm{T}_{4}$ with a value of $25,26 \mathrm{~kg} \mathrm{MS} \mathrm{ha}^{-1} \mathrm{~mm}^{-1}$.

In treatment $T_{3}$, WUE values before anthesis (tillering to panicle emergency) were higher than those determined by Cantero-Martínez et al. ${ }^{32}$ who obtained values that ranged from 11,3 a37,5 $\mathrm{kg}$ MS $\mathrm{ha}^{-1} \mathrm{~mm}^{-1}$ in barley and in a similar period. However, values WUE corresponding to post-anthesis (milky to dough grain) weresimilar to 
the values reported by Cantero-Martínez et al. ${ }^{32}$ that ranged from 13,2 a49 $\mathrm{kg} \mathrm{MS} \mathrm{ha}^{-1} \mathrm{~mm}^{-1}$.

Although the $\mathrm{T}_{2}$ showed a higher WUE value during T-PE and PEMG in comparison with values obtained in treatments $\mathrm{T}_{1}$ and $\mathrm{T}_{4}$, the effect during the vegetative phase is less effective to increase yield since WUE decreased to $6,77 \mathrm{~kg} \mathrm{MS} \mathrm{ha}{ }^{-1} \mathrm{~mm}^{-1}$ between MG-DG.
All the treatments showed a higher WUE between PE-MG (Figure 6). The lowest WUE value was observed between MG-DG for all treatments due to lower volumetric soil water content close to PWP in dough grain, limiting the water uptake due to lower potential gradient soil-roots. This results is in agreement with Ehlers ${ }^{33}$ who reported a lower WUE value in the same phenological stage in oats.

Table 6 Harvest index $(\mathrm{HI})$ of an oat crop with different nitrogen fertilizer sources and lime applications under no-tillage management in a Typic Haploxer and soil

\begin{tabular}{lll}
\hline Treatments & Grain(kg ha-I) & Dry Matter(kg ha-I)Hí \\
\hline TI & $344098790,35 \mathrm{a}$ & $82350,19 \mathrm{a}$ \\
T2 & 1570 & 12 \\
T3 & 4599 & $0,38 \mathrm{a}$ \\
T4 & 465011.156 & $0,42 \mathrm{a}$
\end{tabular}

Column with different lowercase letters differ significantly, Tukey's test $(P \leq 0.05)$

Table 7 Water use efficiency ( $\left.\mathrm{kg} \mathrm{MS} \mathrm{ha}{ }^{-1} \mathrm{~mm}^{-1}\right)$ in the different phenological stages of an oat crop under no-tillage management with different nitrogen fertilization sources and lime applications in a Typic Haploxer and soil

\begin{tabular}{llll}
\hline \multicolumn{4}{l}{ Phenologicalstage } \\
\cline { 2 - 4 } Treatments & T- PE & PE - MG & MG- DG \\
\hline TI & $25,65 \mathrm{aA}$ & $45,87 \mathrm{aA}$ & $19,02 \mathrm{aA}$ \\
T2 & $37,02 \mathrm{aAB}$ & $45,76 \mathrm{aB}$ & $6,77 \mathrm{bA}$ \\
T3 & $42,34 \mathrm{aA}$ & $50,42 \mathrm{aA}$ & $23,58 \mathrm{aA}$ \\
T4 & $35,63 \mathrm{aA}$ & $39,13 \mathrm{aA}$ & $25,26 \mathrm{aA}$ \\
CV\% & 28,36 & 37,91 & 95,5 \\
LSD & 26,07 & 48,61 & 56,55
\end{tabular}

Columns with diferent lowercase letters and files with different capital letters differ significantly, Tukey's test (P<0.05). T: tillering; PE: panicle emergence; MG: milky grain; DG: dough grain; CV: coefficient of variation; LSD: least significant difference

Table 8 Use efficiency $\left(\mathrm{kg} \mathrm{ha}^{-1} \mathrm{~mm}^{-1}\right)$ in an oat crop under no-tillage management with different nitrogen fertilizer sources and lime applications in a Typic Haploxer and soil

\begin{tabular}{lll}
\hline Treatments & WUE dry matter & WUE grain \\
\hline TI & $28,2 \mathrm{a}$ & $9,50 \mathrm{ab}$ \\
T2 & $27,4 \mathrm{a}$ & $5,38 \mathrm{a}$ \\
T3 & $34, \mathrm{Ia}$ & $13,06 \mathrm{~b}$ \\
T4 & $30,6 \mathrm{a}$ & $13,07 \mathrm{~b}$ \\
CV\% & 37,19 & 19,42 \\
LSD & 29,42 & 5,35 \\
\hline
\end{tabular}

Columns with different lower case letters differ significantly, Tukey's test $(P \leq 0.05)$ 


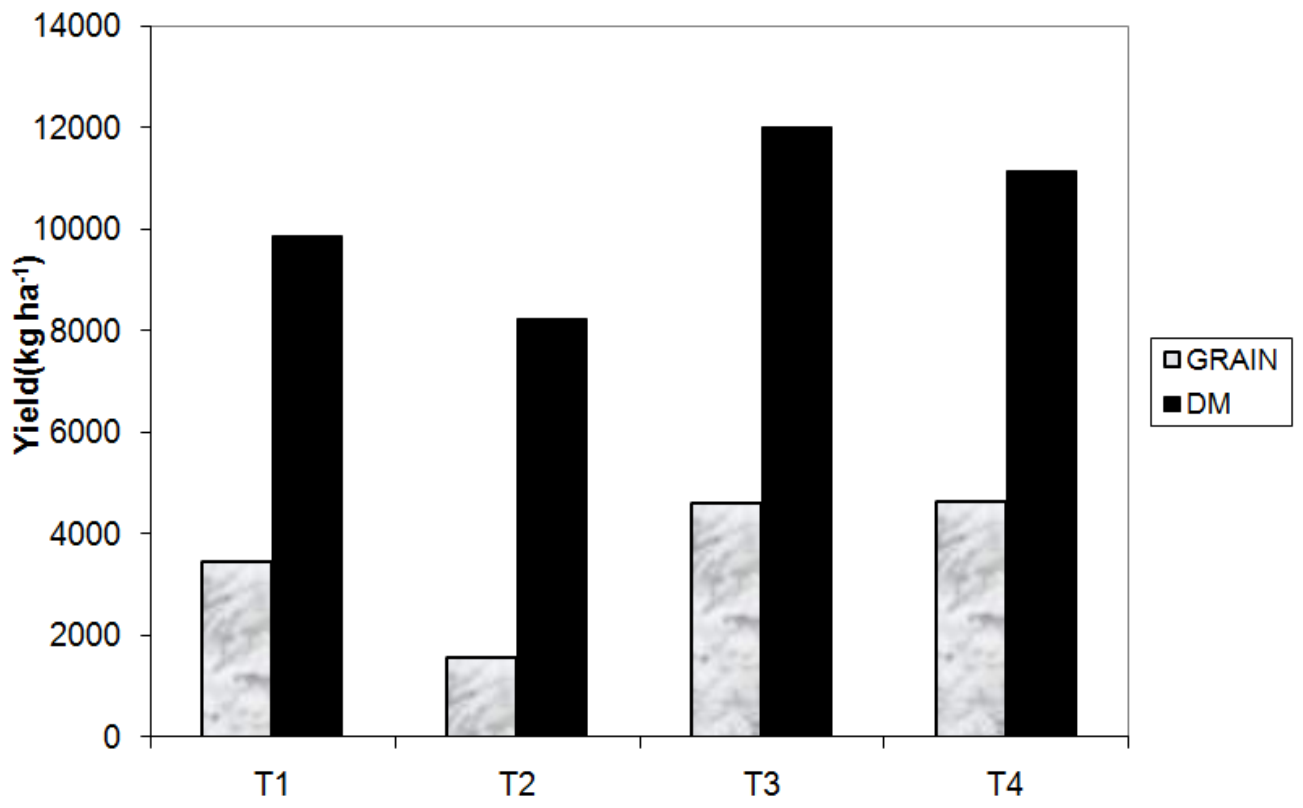

Figure 5 Grain and dry matter (DM) yield of an oat crop with different nitrogen fertilizer sources and lime applications under no-tillage management in a Typic Haploxer and soil.

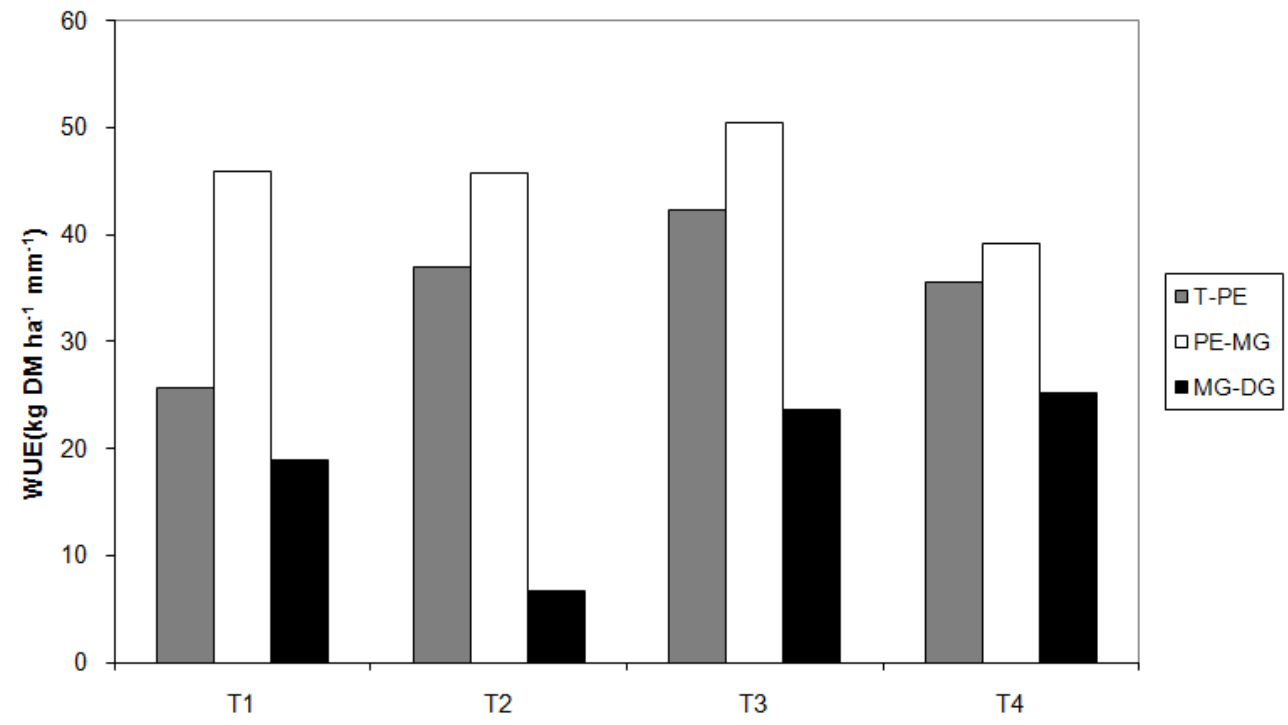

Figure 6 Water use efficiency $\left(\mathrm{kg} \mathrm{ha}^{-1} \mathrm{~mm}^{-1}\right)$ in the different phonological stages of an oat crop under no-tillage management with different nitrogen fertilizer sources and lime applications in a Typic Haploxer and soil.

T, tillering; PE, panicle emergence; MG, milky grain; DG, dough grain.

WUE values for dry matter (Table 8 \& Figure 7)) found in this study were lower than those reported by Ehlers ${ }^{33}$ and Cantero-Martínez et al. ${ }^{32}$ Values ranged from $41 \mathrm{~kg}$ MS ha ${ }^{-1} \mathrm{~mm}^{-1}$ in oats to $38,7 \mathrm{~kg}$ MS ha${ }^{1} \mathrm{~mm}^{-1}$ in barley, but were higher than the results findings in wheat by Li et al. ${ }^{34}$ values that ranged from 7.39 a $14,3 \mathrm{~kg} \mathrm{ha}^{-1} \mathrm{~mm}^{-1}$. Reasons for these differences can be related with the photosynthetic efficiency reported by Fischer and Turner, ${ }^{35}$ who indicated that more efficient plant as CAM and $\mathrm{C} 4$ produced $34 \mathrm{~kg} \mathrm{MS} \mathrm{ha}^{-1} \mathrm{~mm}^{-1}$ as compared with plants C3 with $15 \mathrm{~kg} \mathrm{MS} \mathrm{ha-1} \mathrm{mm}^{-1}$.

Grain WUE (Table 8 \& Figure 7) showed significant differences $(p \leq 0,05)$ among treatments, being the T2 the lowest WUE with 5.38 $\mathrm{kg}$ grain ha-1 $\mathrm{mm}^{-1}$. Treatments $\mathrm{T}_{3}$ and $\mathrm{T}_{4}$ showed the highest WUE as compared with other treatments. These results are in agreement with the results reported by Cantero-Martínez et al. ${ }^{32}$ in barley with 13,77 $\mathrm{kg}$ grain $\mathrm{ha}^{-1} \mathrm{~mm}^{-1}$.As compared with wheat, WUE was higher than the value reported by Li et al. ${ }^{34}$ with a value of $4.99 \mathrm{~kg}$ grano $\mathrm{ha}^{-1} \mathrm{~mm}^{-1}$ but lower than the value reported by Ilbeyi et al. ${ }^{36}$ with a value of 18,2 $\mathrm{kg}$ grain $\mathrm{ha}^{-1} \mathrm{~mm}^{-1}$. According to the results obtained in our study, it is possible to use of ammonium fertilizers with lime additions in order to increase WUE and improve particles aggregation and water storage in acid soils of rainfed areas. ${ }^{37}$ 


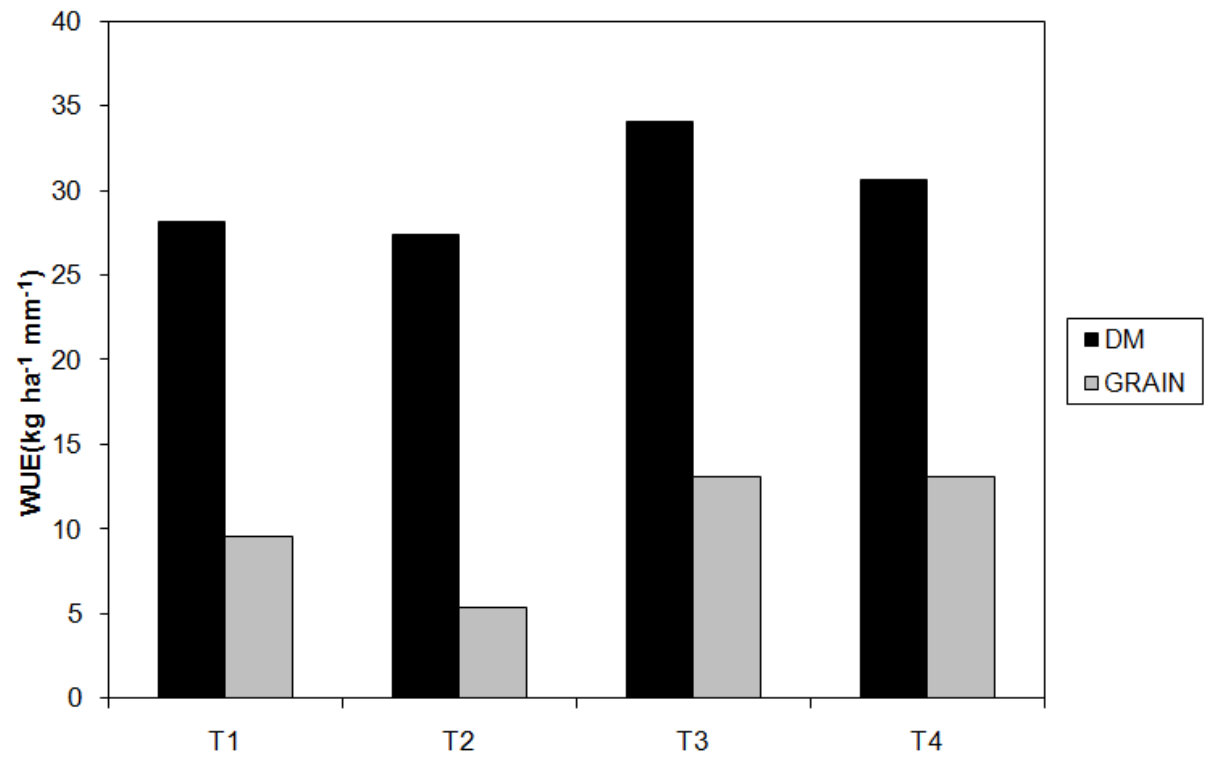

Figure 7 Water use efficiency $\left(\mathrm{kg} \mathrm{ha}^{-1} \mathrm{~mm}^{-1}\right)$ per dry matter and grain yield in an oat crop under no-tillage management with different nitrogen fertilizer sources and lime applications in a Typic Haploxer and soil.

\section{Conclusion}

The deficit and high variability of rainfall in rainfedareas make necessary to study the effect of soil management practices and fertilization on water storage within soil profile and water use efficiency. In the present study, it was found that the use of ammonium nitrogen sources with lime additions increased WUE, dry matter production and grain yield in an oat crop with no-tillage management. Regarding the phenological stages, the highest WUE value was observed between panicle emergence and milky grain. On the contrary, ammoniun fertilization (T2) showed the lowest WUE, growth rate in the grain filling period and a lower harvest index. Soil acidification decreased water and nutrients roots uptake. Treatment T3 with ammonium fertilizers and $750 \mathrm{~kg}$ lime ha ${ }^{1}$ showed the highest WUE. On the other hand, the nitrogen fertilizer sources had no effects on crop evapotranspiration or soil water storage. Based on these findings, the application of ammoniacal fertilizer sources with lime additions in Chilean Andisols are recommended to improve precipitation use efficiency in oat crop under no-tillage management.

\section{Acknowledgments}

None.

\section{Conflicts of interest}

Authors declare no conflict of interest exists.

\section{References}

1. Fereres E, Soriano MA. Deficit irrigation for reducing agricultural water use. J Exp Bot. 2007;58(2):147-159.

2. Alí M, Taludaker M. Increasing water productivity in crop production-A synthesis. Agric Water Manage. 2008;95:1201-1213.

3. Hsiao TC, Steduto P, Fereres E. A systematic and quantitative approach to improve water use efficiency in agriculture. Irrig Sci. 2007;25:209-231.

4. Sharma BR, RaoKV, Vittal KPR, et al. Estimating the potential of rainfed agriculture in India: Prospects for water productivity improvements. Agric Water Manage. 2010;97(1):23-30.
5. Rockström J, Karlberg L, Wani SP, et al. Managing water in rainfed agriculture-The need for a paradigm shift. Agric Water Manage. 2010;97(4):543-550.

6. van Halsema GE, Vincent L. Efficiency and productivity terms for water management: A matter of contextual relativism versus general absolutism. Agric Water Manage. 2011;1018(15):9-15.

7. Angus JF, van Herwaarden AF. Increasing water use and water use efficiency in dryland wheat. Agron J. 2001;93:290-298.

8. Hatfield J, SauerT, Prueger J. Managing soils to achieve greater water use efficiency: a review. Agron J. 2001;93(2):271-280.

9. Condon A, Farquhar G, Richards R. Genotypic variation carbon isotope discrimination and transpiration efficiency in wheat. Leaf gas exchange whole plant studies. Aust J Plant Physiol. 1990;17:9-22.

10. Sinclair TR, Tanner CB, Bennett J. Water-use efficiency in crop production. Bio Science. 1984;34:36-40.

11. Howell T. Enhancing water use efficiency in irrigated agriculture. Agron J. 2001;93:281-289.

12. Munawar A, Blevins RL, Frye WW, et al. Tillage and cover crop management for soil and water conservation. Agron J. 1990;82: 773-777.

13. Tanaka DL, Anderson RL. Soil water storage and precipitation storage efficiency of conservation tillage systems. J Soil Water Conserv. 1997;52:363-367

14. Fengyun Z, Pute W, Xining Z, et al. Effects of conservation tillage on soil water regimes and water use efficiency in farmland of Heithe River Basin in Northwest China. Afr J Agric Res. 2011;6:5959-5966.

15. Feng G, Sharratt B, Young F. Influence of long-term tillage and crop rotations on soil hydraulic properties in the US Pacific Northwest-J. Soil Water Cons. 2011;66:233-241.

16. Pannkuk CD, Papendick RI, Saxton KE. Fallow management effects on soil water storage and wheat yields in the Pacific Northwest. Agron J. 1997;89:386-391

17. Moret D, Arrúe JL, López MV, et al. Influence of fallowing practices on soil water and precipitation storage efficiency in semiarid Aragon (NE Spain)- Agric. Water Manage. 2006;82:161-176. 
18. Deng X-P, Shan L, Zhang H, et al. Improving agricultural water use efficiency in arid and semiarid areas of China. Agric Water Manage. 2006;80:23-40.

19. Fuentes JP, Flury M, Huggins DR, et al. Soil water and nitrogen dynamics in dryland cropping systems of Washington State, USA. Soil Tillage Res. $2003 ; 71: 33-47$.

20. Pala M, Ryan J, Zhang H, et al. Water-use efficiency of wheat-based rotation systems in a Mediterranean environment. Agric Water Manage. 2007;93:136-144.

21. Adamtey N, Cofie O, Ofosu-Budu KG, et al. Effect of N-enriched compost on transpiration efficiency and water-use efficiency of maize(Zea mays L.) under controlled irrigation. Agric Water Manage. 2010;97:995-1005.

22. Mora ML, Alfaro MA, Jarvis SC, et al. Soil aluminium availability in Andisols of southern Chile and its effect on forage production and animal metabolism. Soil Use Manage. 2006;22(1):95-101.

23. Lampurlanés J, Cantero-Martínez C. Hydraulic conductivity, residue cover and soil surface roughness under different tillage systems in semiarid conditions. Soil Tillage Res. 2006;85:13-26.

24. Jin H, Qingjie W, Hongwen L, et al. Effect of alternative tillage and residue cover on yield and water use efficiency in annual double cropping system in North China Plain. Soil Tillage Res. 2009;104(1):198-205.

25. Jalota SK, Arora VK. Model-based assessment of water balance components under different cropping systems in north-west India. Agric Water Manage. 2002;57:75-87.

26. Pozo A del, del Canto P. Áreas agroclimáticas y sistemas productivos en la VII y VIII regiones. INIA Quilamapu. Chillán, Chile. 1999.

27. Balzarini M, Gonzalez L, Tablada E, et al. Infostat: software estadístico: manual del usuario. Versión 2004. Brujas Argentinas. Córdoba, Argentina. 2004
28. Nissen J, Quiroiz C, Seguel O, et al. Non saturated water movement in Andisols. R C Nutr Veg. 2006;6:9-19.

29. Tan CS, Drury CF, Gaynor JD, et al. Effect of tillage and water table control on evapotranspiration, surface runoff, tile drainage and soil water content under maize on a clay loam soil. Agric Water Manage. 2002;54:173-188

30. Ribera A, Mora ML, Ghiselini V, et al. Phosphorus -molybdenum relationship in soil and red clover (Trifoliumpratense L.) on an acid Andisol. J Soil Sci Plant Nutr. 2010;10:78-91.

31. Caviglia O, Sadras V. Effect of nitrogen supply on crop conductance, waterand radiation-use efficiency of wheat. Field Crops Res. 2001;69:259-266.

32. Cantero-Martínez C, Angas P, Lampurlanés J. Growth, yield and water productivity of barley (Hordeumvulgare L.) affected by tillage and $\mathrm{N}$ fertilization in mediterranean semiarid, rainfed conditions of Spain. Field Crops Res. 2003;84:341-357.

33. Ehlers W. Transpiration efficiency of oat. Agron J. 1989;81(5):810-817.

34. Li Z-Z, Li W-D, Li W-L. Dry-period irrigation and fertilizer application affect water use and yield of spring wheat in semi-arid regions. Agric Water Manage. 2004;65:133-143.

35. Fischer R, Turner N. Plant productivity in the arid and semiarid zones. Annual Rev Plant Physiol. 1978;29:277-317.

36. Ilbeyi A, Ustun $\mathrm{H}$, Oweis $\mathrm{T}$, et al. Wheat water productivity and yield in a cool highland environment: effect of early sowing with supplemental irrigation. Agric Water Manage. 2013;82(3):399-410.

37. Claussen W. Growth, water use efficiency, and proline content of hydroponically grown tomato plants as affected by nitrogen source and nutrient concentration. Plant Soil. 2002;247:199-209. 